archives-ouvertes

\title{
Migration Policy Development in Mauritania: Process, Issues, and Actors
}

Philippe Poutignat, Jocelyne Streiff-Fénart

\section{To cite this version:}

Philippe Poutignat, Jocelyne Streiff-Fénart. Migration Policy Development in Mauritania: Process, Issues, and Actors. Geiger Martin \& Pecoud Antoine. The Politics of International Migration Management, Palgrave Macmillan, pp.202-219, 2010, 978-0-333-71047-0. halshs-00962124v2

\section{HAL Id: halshs-00962124 \\ https://halshs.archives-ouvertes.fr/halshs-00962124v2}

Submitted on 17 Oct 2019

HAL is a multi-disciplinary open access archive for the deposit and dissemination of scientific research documents, whether they are published or not. The documents may come from teaching and research institutions in France or abroad, or from public or private research centers.
L'archive ouverte pluridisciplinaire HAL, est destinée au dépôt et à la diffusion de documents scientifiques de niveau recherche, publiés ou non, émanant des établissements d'enseignement et de recherche français ou étrangers, des laboratoires publics ou privés. 
Migration policy development in Mauitania: process, issues and actors

Philippe Poutignat \& Jocelyne Streiff-Fénart, University of Nice, IRD, CNRS (France)

Over the course of the last decade, several characteristics have earmarked Mauritania as a testing ground for European policies of migration. As a gateway to Europe on account of the relative proximity of its coastline to the Spanish Canary Islands, the economic capital of Mauritania - Nouadhibou - provides a strategic location for testing the efficiency of the containment measures implemented as part of the externalisation of European policies of migration and asylum (Streiff-Fenart \& Poutignat, 2008). Within the framework of the "migration routes" approach which defines the positions adopted by EU partners in relation to the implementation of these policies, Mauritania's limited migration flow towards Europe also provides a paradigmatic case of "transit countries".

Other significant characteristics have tended nonetheless to contradict efforts to transform southern countries into partners of international border control policies and to impose a conception of border control as a shared issue. The lack of interest in migration shown by the government, public opinion and civil society (which have tended to display far greater interest in the internal challenges raised by slavery and the return of refugees to Senegal ${ }^{1}$ ) has been a recurrent feature of reports published by international organizations ${ }^{2}$. Compared with the prevailing situation in neighbouring countries also concerned by the European externalization of asylum and migration (particularly Senegal), the management of migration flows in Mauritania has not had the same impact on the country's political agenda and on societal debates. The consensus on the status of Mauritania as a "transit country" means that the issue is seen as being merely of indirect concern to the country and to the Mauritanian population. Expressions of support for deported immigrants from Spain in Senegal, which compelled the government to temporarily suspend its agreements with Spain, are largely irrelevant in the Mauritanian context. The marked contrast between the 2007 presidential campaigns conducted at roughly the same time in Senegal and in Mauritania is also noteworthy: unlike Senegal, the programmes of presidential candidates in Mauritania did not emphasize migration as a key political issue.

1 See Fresia 2009 and footnote 15 in this paper.

2 See for instance this conclusion from the first "Migration Profile of Mauritania" produced in 2006 by the IOM, the HCR and the EU: "It has emerged from interviews with government representatives that there is no national policy of migration in Mauritania" (document appended to the "Document Stratégie Pays" on Mauritania, which be an accessed http://ec/europa.eu/development/icenter/repository/scanned_mr_csp10 fr.pdf). The report by the Robert Schuman Centre on Illegal Migration in Mauritania emphasizes from the very outset that "in Mauritania the issue of immigration has been ignored for many years" (Mohamed Saleh, 2008). The report on "Migrations in Mauritania. 2009 Migration Profile" produced by the IOM again emphasizes the inadequacies of the current legislative framework, which does not "enable a proper management of the emerging issues of migration". The document can be downloaded on the website of the IOM at http://publications.iom.int/bookstore/index.php?main _page=index\&language $=\mathrm{fr}$ 
It remains nonetheless that successive Mauritanian governments since the 2005 coup d'état $^{3}$ have tended to found their quest for international recognition on the willingness of Mauritania to respond to EU injunctions on the control of migration flows. In late 2006, the president of the CMJD could thus claim - with good reason - to be the "star pupil" of the partnership policy: "Today, Mauritania is a key actor in the Maghreb, Africa and other geopolitical areas. Whether it be the fight against illegal immigration or the Barcelona process, our country is a sincere and reliable partner" ("Horizons", 29/11/06).

Mauritania is increasingly asserting itself as a secondary actor on the European political stage, in solidarity with the positions adopted by Spain and, at a still higher level, by the European Commission. But the process of alignment has entailed a degree of political manoeuvring by Mauritania, with the country adjusting only partially and opting resolutely to play its own hand. There has a been significant shift in the last five years: while Mauritania's policy of migration had previously been the object of largely external actions designed to implement control mechanisms of the most operational kind (i.e. military and police control), key aspects of this policy have recently been reformulated and internalized. Mauritanian institutions and civil society have been required to adopt a position on the issue of migration following the implementation of the programmes conducted by international organizations (funded primarily by the EU and Spain) aimed at translating the long-term objectives defined by the various partnerships into concrete actions ${ }^{4}$.

This article will examine the various phases of an on-going process that has resulted in a negotiated alignment of Mauritania with the targets assigned to "transit countries". In the course of this process, the external and internal implications of the issue of migration in Mauritania have become varyingly embedded as a result of different strategies, while ideas and words drawn from migration management have been subject to appropriation, reformulation and, more rarely, opposition.

\section{The "policy of migration" in Mauritania: a concept under influence}

As in other countries, international organizations (IOM, HCR, ILO) in Mauritania perform a key role in the transfer of cognitive categories and frameworks used by countries in the North to interpret phenomena of migration. The activities of these organizations are not merely focused on international meetings or conferences and their preparatory or resulting texts, since they are also performed "on the ground". Alongside the technological instruments required for the control of migration flows, international experts provide the discourse (the fight against smuggling and trafficking, human rights, good governance, development, decent work) upon which management mechanisms

3 On August 3 2005, the 20-year authoritarian regime of Colonel Maouyyia Ould Sid'Ahmed Taya was overthrown by a putsch, resulting in the creation of a transitional government - the Military Committee for Justice and Democracy (CMJD) - which initiated an electoral process that produced a democratically elected government in 2007, which was itself overthrown by the coup d'état of August 2009. The leader of the coup, General Mohammed Ould Abdel Aziz, was elected president in the elections of July 2009.

4 "5+5", Euro-African dialogue, EU-AU, EU-ECOWAS, EU-ACP... 
depend for their acceptance and legitimacy. The implementation of the "external dimension" of the EU's policy of migration and asylum was immediately accompanied by efforts to impose the question of illegality (Ben Saâd 2008). Changing the representations of legal migrants (within the country) as potential illegal immigrants (in Europe) has emerged as a central objective for the bodies in charge of managing migration flows. These organizations have unanimously deplored the lack of urgency of the Mauritanian authorities in endorsing the objectives assigned to transit countries, but also the porosity of its borders, the freedom of circulation enjoyed by the citizens of bordering countries, and a generally benevolent attitude toward foreigners within Mauritanian society, a feature attributed to the nomadic culture of Mauritania ${ }^{5}$. The same organizations have also expressed concerns over the limited willingness shown by the authorities to initiate reforms aimed at challenging an administrative system which subjects migrants to harassment and informal levying independently of their legal status.

In 2006, the efforts to impose the issue of illegality resulted in the creation of a branch of the IOM in Nouakchott as a result of a technical assistance programme implemented (with varying degrees of success) to support the management of migration. This has been aimed as much at the fight against illegal immigration as at the creation of the conditions of migration policies designed to guarantee the illegalization of migrants ${ }^{6}$ : alongside measures aimed at improving border control (such as training border police to detect fake passports), the "reinforcement of capabilities" targeted by this programme made provision for the organization of seminars for magistrates, with a view to encouraging the country to develop a legal framework adapted "to the reality of international migrant trafficking". Note in this respect that the primary objective was not to ensure that the authorities sanctioned smugglers so much as to guarantee that they applied the "right" charge that would make the condemnation of illegal immigration and the criminalization of trafficking fully manifest. In a 2007 interview $^{7}$, the manager of the Nouakchott branch of the IOM made (indignant) reference to cases in which smugglers had been charged with forgery and the use of forgeries instead of migrant trafficking ${ }^{8}$.

5 For example: "until recently the Mauritanian people, heavily imbued with nomadic traditions, held no particular views on the populations transiting through their land since the Mauritanians thems were subject to permanent movement". Translated from Haimoud Ramdan: La législation de la migration et des travailleurs migrants en Mauritanie, ILO, June 2005, p.30. Also: "The issue of migration flows, which had until now been largely ignored in a culturally nomadic country in which a foreigner could not possibly represent a threat, is now addressed by the Mauritanian authorities". Translated from key document of the 2007-2011 Franco-Mauritanian Partnership, p.7 (Partenariat France-Mauritanie 20072011), p.7 (see http://www.diplomatie.gouv.fr/fr/).

6 The process of illegalization implies considering migrants as objects of "illegal trafficking". It is worth noting that in the document on human rights published by the IOM, illegal migrants are not viewed as a "vulnerable" category alongside women and children, and the measures that concern them pertain exclusively to sanctions applying to those helping them to immigrate or find employment ("Migration et protection des Droits de l'Homme", Droit de la Migration no3, IOM 2005, p.103).

7 The interviews quoted in this article were conducted in the course of a series of studies carried out in Nouakchott and Nouadhibou in 2007 and 2010 as part of a research programme on transit migrations in Africa (MITRANS) funded by the National Research Agency (Agence Nationale de la Recherche).

8 Worse still (from the point of view of the IOM), the authors of this study were provided with examples of cases in which indelicate smugglers were required to repay the "illegal" migrants whom they had been unable to bring to their destination. More than a flaw in the legislative apparatus, these "legal anomalies" testify to the gap between the conceptions of "good governance" upheld by international 
Several factors account for the lack of urgency displayed by the Mauritanian state in devising a migration policy worthy of the name (a fact deplored by international organizations), including the fact that the country is significantly integrated at a regional level'. Mauritania's policy of migration (or "lack" thereof) takes account of this fact. Yet the country is heavily involved in the Euro-Mediterranean partnership process, which is partly aimed at managing migration flows. Mauritania has been participating in the Barcelona process and in Euro-Mediterranean consultation and dialogue since 2007. Since 2004 Mauritania has been a member of the 5+5 group, and in 2008 it became a founding member of the Mediterranean Union. As a result of this partnership, there has been a succession of multilateral meetings and concerted action plans since 2004 that have been aimed at strengthening the control and management of illegal migration.

In 2004, a project entitled Preliminary Actions: Capacity Building of Migration Management in Mauritania was integrated within the remit of IOM funding. The project was designed as a response to a demand made by the Mauritanian government, which, "following the recent increase of illegal migration, is asking for help in order to implement coordinated and efficient measures against this trend. The IOM will help the Mauritanian government (...) to evaluate and improve its capability (...), which includes the development of a national programme of migration management".

On the initiative of the HCR, a forum on migration issues was created in early 2005 under the aegis of the Interior Ministry, which eventually became the Groupe d'Etude des Flux Migratoires (Study group on Migration Flows). Following meetings held in September 2005 and again in February 2006, the purpose of the group is to conduct research on national and international law, administrative management and the socioeconomic conditions of the period spent by migrant refugees in Mauritania.

Late 2005 (a period marked by the "Ceuta and Melilla events") saw the implementation of the Seahorse and Atlantis projects of the Guardia Civil and the Spanish Interior Ministry (involving Mauritania, Morocco, Senegal and Cap-Vert), which were aimed at "fostering greater collaboration between the country of origin, the transit country and the country of destination of illegal immigrants" with a view to fighting more efficiently against the "Mafia of human trafficking" at the points of origin. Seahorse is designed to develop the coordination and circulation of information between the various services in charge of fighting illegal immigration, to provide training for the agents in charge of migration management and control, and to create a network of liaison officers. One specific objective in Mauritania is the development of a maritime service capable of preventing illegal immigration. Atlantis aims to create multinational maritime patrol units. Some of the underlying motivations include the modification of maritime routes and the alteration of the methods implemented by the "Mafia" to reach the Canary

organizations and a moral economy (Olivier de Sardan, 1996) in which the disapproval of practices that contravene business ethics is combined with a high level of tolerance of practices infused with illegality.

9 Although Mauritania withdrew from the Economic Community of West African States (ECOWAS) in 2009, the bilateral agreements on the circulation of people were not repealed. Citizens from Mali and Senegal - member states, with Mauritania, of the Organization for the Promotion of the Senegal River enjoy a special status. 
Islands, made predictable by the implementation of the SIVE detection system ${ }^{10}$. The project identifies Nouakschott and Nouadhibou as ports harbouring over 3000 fishing vessels "suspected of being involved in activities relating to illegal immigration".

2006 was marked by a high degree of media interest in the arrival of pirogues on the Canary Islands from the Mauritanian (and subsequently Senegalese) coasts. The "influx of illegal immigrants" in the Canary Islands (or the "wave" or "avalanche" of illegal immigrants - all words used in the press and by the authorities, particularly in the Canary Islands) precipitated the implementation of "action priorities" adopted in late 2005 by the European Commission and the European Council. The Spanish government became the target of criticisms from right-wing opposition parties (which criticized it for being excessively "lax" and for the recent legalization of 500,000 immigrants) and of appeals made by the regional Canary Islands government (opposition). The result was a largescale lobbying campaign conducted by the Spanish government and directed at European institutions and other member states. The Spanish authorities also sought to involve countries of origin and transit countries in Africa in the fight against illegal immigration (in line with the global approach doctrine ${ }^{11}$ ) by launching an "Africa plan" in June 2006. The "migration crisis" in the Canary Islands, the agreements between Mauritania and Spain and the requests for aid submitted to the EU, in addition to the press releases published at the time, constituted a first phase in the alignment of Mauritania with European strategies aimed at developing its priority actions "in partnership".

\section{The alignment of Mauritania: a political and discursive positioning}

Since March 2006, the phrase "migration crisis", which had already been used at the time of the Ceuta and Melilla events, has been recurrently used not merely in the press but also in official statements and speeches issued by the authorities (Canary Islands, Spain, Europe, Mauritania...) to describe the new situation. Though presented as "the challenge of illegal immigration and the resulting human tragedies" requiring emergency measures, the "migration crisis" in the Canary Islands was not a raw, unmediated fact. Rather, it encapsulates a situation elaborated and articulated discursively in a political debate that

10 The integrated system of external vigilance, which has been operational since 2002, was implemented by the Spanish Civil Guard and funded by the European Union. It involves a sophisticated system of radars, cameras and sensors. Designed to monitor maritime borders, it was initially installed in the Strait of Gibraltar, and was gradually extended to the Canary Islands, the Andalusia coastline and the Balearic Islands to cover all of Spain's maritime borders.

11 Following the statement published by the European Commission entitled "Priorités d'action en vue de relever les défis liés aux migrations" [COM (2005) 621 final; Action priorities aimed at responding to the challenges of migration], the European Council adopted the "global approach" in December 2005. The global approach views the immediate measures designed "to reduce illegal immigration flows" as part of a "broader objective" aimed at developing relations between the EU, Africa and countries of the Mediterranean as part of a "genuine partnership". As a result of this partnership, the global approach will regroup the policies of the European Union in the areas of migration, external relations and development. Conceived as the framework of reference at the Euro-African ministerial conferences held in Rabat (2006) and Paris (2008) and at a large number of expert meetings leading up to these conferences, the "global approach" is summarized in the three targets of the resulting action plans: the fight against illegal immigration, the reinforcement of the relations between immigration and development, and the organization of legal circulation. 
extends to regional, national, European and international levels (Carrera, 2007). The primarily political construction of the migration issue (to which the media contributed nonetheless significantly) was apparent for instance in the repeated use of a rhetorical format highlighting more or less coherent sets of statistics with a view to establishing the enormous, exceptional and unprecedented influx of migrants. On March 4, a regional information website claimed that "[s]ince the beginning of the year, nearly 1480 immigrants have reached the coasts of the Canary Islands, i.e. nearly 540 more than the number of immigrants who arrived on the islands during the first two months of 2005 (944) (...) January was the best month, with 17 pateras and 598 immigrants (as opposed to 492 in 2005) (...) In February the number of immigrants almost doubled - 884 immigrants arrived as opposed to 452 immigrants during the same period in 2005"12. The same format was used ad nauseam all throughout the "crisis" and compares the number of arrivals at a given moment $X$ in 2006 with a statistic deemed to be significant (albeit variable) drawn from previous years: "as many as in the first six months of 2005", "more than the entire number of arrivals in 2005", "...will double, triple, quadruple compared with last year", "will smash the previous year's record in the first half of this year..." etc. The discourse tends towards the conclusion that these are unprecedented facts, though subsequently the opposing thesis was firmly re-established. De Haas (2007, 2008) in particular spoke of the "myth of invasion" and demonstrated that it is neither a new nor a large-scale phenomenon.

The Mauritanian authorities played a key role in the development of an exceptional situation that largely shaped the country's discursive and political alignment with Spain and the EU. For instance, the Prime Minister made the following statement in an interview published in El Pais: "What happened was unimaginable. In 2005, we arrested 3900 illegal immigrants who were about to enter the Canary Islands, and within the space of just two months (since the beginning of 2006) we have arrested a further 1200".

The discursive construction of the "migration crisis", construed as an exceptional situation justifying urgent new measures, cannot be dissociated from the discursive construction of the "human tragedy", which raises the issue of the moral responsibility of the drownings and suffering of migrants. The consensual interpretation of these tragedies, which tends to emphasize the view of migrants as the victims of smugglers ("human traffickers"), but also and above all of themselves (on account of their irrational determination and naivety), fosters a vision of migration as a "suicidal" act that involves both paternalistic justifications (protecting reckless victims) and legalistic justifications (arresting and punishing the villains). The means deployed to prevent their arrival were presented as the foundation of a veritable rescue mission. Saving lives is assumed to be a virtuous consequence of measures that are designed primarily to prevent a "massive influx" onto European soil. While they serve to legitimize the political engagement of Mauritania alongside Europe ${ }^{13}$, the coordinated efforts to prevent these "collective

12 Source: Terra Actualidad - Vocento/VMT. (Dispatch quoted on the "Migreurop" list by the AFVIC/PFM on March 4 2006).

13 The engagement was described as an involvement in "joint surveillance operations (...) diverting the vessels using this migration route and contributing to the reduction of human lives lost at sea", to quote the description of operation Hera II by Frontex on its website. 
suicides" contribute to Mauritania's alignment with the discursive repertoire used by the EU to describe the phenomenon ("illegal immigration") or to formulate solutions ("partnership", "reinforcement of capabilities").

The commitment of Mauritania was made official in 2006 by the adoption of "a strategy of prevention of African illegal immigration towards Europe from its own territory, through the reinforcement of surveillance and the search for smugglers". But the plan (which was presented as requiring a significant mobilization of means) was largely declarative since Mauritania's material equipment was relatively limited and for the most part out of service. Yet Spain was prompted within a matter day to insist during a ministerial "crisis" meeting on the need for an "emergency cooperation plan with Mauritania". The very next day, the Prime Minister of Mauritania declared that "Mauritania cannot by itself deal with this kind of phenomenon, indicating that he hoped the EU and more specifically the Kingdom of Spain would support the Mauritanian government".

Cooperation between the two countries was made effective by the creation of joint patrol units that became operational in May. These patrols were a first of sorts, since never before had the EU funded an operation designed to "fight against illegal immigration" affecting a third-party country, a fact underlined by the Spanish and European authorities. The cooperation strategy entailed a military presence, including both material (ships, helicopters) and human resources that replaced local forces while aiming to provide training for the latter - in keeping with the classical model of policies of cooperation.

Spanish-Mauritanian cooperation also resulted in the creation of a transit centre in Nouadhibou. The degree of indecision in naming the centre - with a greater or lesser emphasis on humanitarian priorities ("temporary accommodation camp") or security priorities ("detention camp") - is indicative of the combination of aid and police registers of discourse characteristic of the management of so-called "illegal" migration. The role of the centre was described by the 2009 Migration Profile of Mauritania as the provision of "a port of first assistance" for migrants failing to reach the Canary Islands "with a view to preparing their repatriation to their countries of origin".

The creation of the centre emphasized by the Mauritania plan and for which Spain provided material and human resources provided an opportunity for extending the repatriation agreement signed in 2003 to include the readmission of migrants from thirdparty countries. But it also provided the opportunity for the adoption of public positions in Mauritanian society, which had until then been relatively indifferent to the question of migration. By transferring the issue of migration onto the question of human rights, the centre imposed the issue on the agenda of associations such as the Association Mauritanienne des Droits de l'Homme (AMDH), which quickly issued a statement opposing the construction of the centre by the Spanish army and criticising the risk of ill treatment. Even if the process of realization was a gradual one, the organization now sees migration as one of its chief priorities on the basis of the respect of rights in keeping with its vocation, which nonetheless implies more directly political positions: the association denounces the agreements with the EU and the role of "gendarme of Europe" which the 
EU expects Mauritania to perform. Beyond the matter of denouncing the infringement of the rights of migrants, in keeping with the themes of mobilization of transnational movements in which it takes part ${ }^{14}$, the "realization" by the AMDH of the importance of the issue of migration reflects specific concerns of Mauritanian society: the ill treatment of Senegalese immigrants, which entails the risk of measures of retaliation, raises the spectre of the events of $1989^{15}$. The leaders of the AMDH are deeply concerned by the threats which the alignment of Mauritania with policies of migration imposed by foreign powers implies for the still fragile balance of the country ${ }^{16}$.

Another reframing was triggered by the discovery of oil on Mauritanian soil in 2005: the status of Mauritania as a transit country, assigned by the partnership policy and vigorously upheld in the negotiation process with the EU, was gradually blurred by an emerging representation of Mauritania as a destination with a strong power of attraction, a kind of little Eldorado at a regional scale, which the discovery of oil would make comparable to the Emirates in the Gulf (Choplin \& Lombard, 2009). Alongside the issue of illegal immigration, which continued to pose a problem in terms of the containment of undesirable flows, there emerged another issue: the integration of immigrants as workers to be included within the urban and economic fabric.

These tendencies are in line with the post-control directions recommended by European institutions as part of a global policy of migration. In June 2007, a meeting was set up between an EU delegation and representatives of the Islamic Republic of Mauritania as part of the emerging political dialogue on migration following the Rabat and Tripoli conferences. The meeting reaffirmed the specific status of Mauritania as a transit country, which was commended for its efforts "in the prevention of and fight against migrants, in spite of limited means, including in the area of readmission and return". The novelty was that the delegations present at the meeting envisaged an increase of immigration with a view to "maximizing benefits" as part of the global migration approach. These suggestions were firmly endorsed by the recommendations outlined in the EU's national incentive programme for the $2008-2013$ period. The programme criticized Mauritania for its excessive focus on security in its management of migration flows. It emphasized that the 2006 national strategy for the fight against illegal immigration (which had nonetheless been adopted under the pressure of Spain, as noted above) "focused on the goal of containing illegal migration flows transiting through the country, without taking account of the potentially useful knock-on effects of migration" (p.19). It recommended a more "positive" management of migration flows, including a reflection on the legalization of migrants seeking to establish themselves on a permanent basis on a given

14 The leader of the AMDH took part in the Bamako social forum, where the decision was taken to hold a demonstration for the rights of migrants and the freedom of circulation on October 72006 . The AMDH leader acted as representative of Mauritania at the "counter-summit" held in Rabat in May-June 2006. The association participates in the regional project for the defence of the rights of migrants in transit countries initiated by the Cimade in 2009.

15 Following a conflict at the border between pastors and riverside villagers living on the shores of the Senegal river, measures of retaliation against Moorish traders in Senegal resulted in massacres of Senegalese citizens in Mauritania. These were followed by massive deportations towards neighbouring countries of several thousands of Negro-African citizens from Mauritania who were denied citizenship.

16 Interview conducted with the chairman of the AMDH in Nouakchott, July 2007. 
territory and their formal integration within the economic sphere (p.40). Finally, the "development" dimension - which had so far been ignored on account of the status of Mauritania as a transit country - was beginning to emerge as a focus of discussion. The text of the common statement that resulted from the EU-IRM meeting held in June 2007 recommends a better integration of the "migration" issue in development strategies and makes the creation of "decent jobs" a priority in areas of high migration. In July 2007, Madrid and Nouakchott signed an agreement designed to promote the legal migration of Mauritanian workers towards Spain. The Mauritanian minister of labour emphasized that the 5000 Mauritanians living in Spain are "legal, fully integrated and have a $0 \%$ rate of criminality".

We are thus seeing the premises of a markedly more complex conception of the migration issue than the vision which construed Mauritania as a transit country determined to ensure the containment of illegal migration flows transiting through the country. Notwithstanding this reconfiguration, the issue of illegality, which (as Bensaâd noted) was imposed in a country where illegality was largely alien to local representations, does not lose its acuteness. It was instead subject to a reconfiguration in a opposition between legal and illegal migration that carried distinct moral connotations: the former associated immigrant workers in Mauritania and potential Mauritanian immigrants towards Europe within the same model of virtuous migration; the latter exclusively concern foreigners, deemed to be undesirable for the local economy and also potentially delinquent.

\section{The co-construction of a policy of migration in Mauritania. Issues and actors.}

The new conception of migration management opens a sphere of public action that largely exceeds the capabilities of traditional forces (police, army, religious and humanitarian associations) dedicated to the management of illegal immigration. The identification of the institutional actors recognized as being involved in the process largely depends on their ability to integrate a transnational network of cooperation that would enable them to establish themselves as "key actors" among those involved in the consultation process. The turn initiated in 2007 in the policy of migration was thus made manifest by the simultaneous creation of organizations that fostered relations between a range of key local, national and supra-national actors. Two of these actors appear to be particularly significant in the emergence of a field of intervention on the issue of migration for meetings between partners with diverging interests, objectives, and remits of action, but (and this is precisely what makes it a field) which are nonetheless interconnected by the shared discursive forms directly imported from the lexicon of "migration management" and combined in a variety of ways.

Created in October 2007, the Mauritanian Association for the Fight Against Illegal Immigration constitutes one of the most visible manifestations of the involvement of civil society in issues of migration management. Composed of lawyers and journalists from the government daily "Horizons", the association is a member of the "Technical group of national work" created by the IOM. As its initials suggest, it presents itself as a guardian of a national cause and is founded on the model of comparable associations designed to conduct "public utility" campaigns created and supported by international organizations 
and ministries keen to reach and even mobilize local populations to fight against a variety of sanitary and/or social "plagues" (such as genital mutilations and malaria). It is involved in an inter-African network of similar associations over which it presides. The sub-regional forum which it set up in June 2008 in Nouakchott in the presence of Mauritanian officials and the IOM representative provided an opportunity for making official its leadership of the management of the fight against illegal immigration. The General Secretary of the Ministry in charge of relations with Parliament and civil society congratulated himself for the organization of "this regional meeting in our country by a national association" and re-emphasized the desire of the President to deploy efforts to "stem the progression of the flow of young people attracted by Western countries". The plague-like nature of illegal immigration implies all at once the epidemic nature of immigration among younger populations, the risk to human life and the negative impact on the countries of origin, the transit countries and the countries of destination, which it exposes to "social, economic and security challenges".

The AMLII claims that transit migrants (from Mali, Senegal, Guinea, Cameroun, Ivory Coast, Gambia and Togo) are its "target group" and that the chief concern of transit migrants "is to work in order to save the 400 to 500 thousand ouguiya required to pay the smugglers for the passage to Europe". The activities of the association contribute to the implementation of "preventative measures designed to dissuade prospective migrants to leave their countries of origin in order to embark on a perilous adventure" (in the words of the phrase retained by the IOM - Migration profile recommendations). The association reformulates it as the consideration of an issue that primarily concerns foreigners, in keeping with the vision of Mauritania as a "transit country". The AMLII signed a contract of collaboration with the Mairie of Sebkha for the apparent reason that a high proportion of foreigners live in Sebkham, as well as a "large number of networks of smugglers".

The Migration Guide Centre created by the General Confederation of Mauritanian Workers constitutes another manifestation of the involvement of civil society in the general set of organizational devices aimed at migration management. The statement made by its coordinator ${ }^{17}$ clearly emphasizes the weight of its presence within this network and the importance of having its specific remit - summarized by the key phrase "decent work" - fully acknowledged: "the work carried out by the migrant centre in Nouakchott has enabled the union to be acknowledged as a key actor in the management of migration flows and the promotion of decent work for migrants".

Funded by the ISCOD (Union Institute of Cooperation) of the Spanish union UGT, and supported by the AECID (Spanish cooperation), the centre takes part in the programme aimed at fostering greater union solidarity - Sud-Sud - created by the CSI between the CNTS union (Senegal) and the CGTM. Its action was immediately integrated within the framework of a joint management of migration and the partnership which it entails, as noted by its first report: "The partners involved in the management of migration issues, such as the PNUD, the IOM and the EU, as well as a number of organizations in

17 This and the following quotations are drawn from an interview conducted with Mamadou Niang, coordinator of the Guide Centre, which can be accessed at www.ituc-csi.org 
Mauritanian civil society, have also been informed in writing of this new measure". The union promotes an approach to migration based on the protection of rights against a purely security-focused and administrative form of management. Its practical objectives are chiefly directed at defending the rights of migrant workers in Mauritania (legalizing the situation of illegal workers, resolving labour conflicts suffered by migrant workers, training female domestics, collaborating with the associations of foreign communities living in Mauritania). Yet the issue of illegal immigration to Europe is not altogether overlooked since it is addressed from the perspective of the information on legislation and the European job market. The centre published an information leaflet for migrants " $t o$ explain who would be eligible to work in Europe, and which formalities and necessary procedures would need to be carried out, because immigrants often arrive with false promises made by organized traffickers" (interview with Mamadou Niang). One of the objectives of the centre is to "inform migrants so that they can make the right decisions and that they are aware of good practices". The provision of information is encouraged both by the ILO and by the IOM, which both publish common information leaflets on the dangers of illegal immigration.

The positions of the two organizations in the context of the specific partnerships in which Mauritania is now involved in the realm of migration reveal the mechanisms of the appropriation of the hegemonic discourse of international organizations and the alignment of the involved parties with the positions assigned by this discourse. They also reveal the implementation of a migration management mechanism that assumes both a distribution of tasks (and of the accompanying rhetoric) between partners and the points of articulation that guarantee its coherence.

Among these points of articulation, it is important to emphasize the common reference to the Law, the procedural dimension of which (ratification of convention, rebuilding of codes) provides the basis of a language that can be appropriated by actors developing lines of action that are not merely different but that could also be deemed to be conflicting: a technocratic engineering of migration management (carried by the IOM) and the defence of the interests of workers (CGTM) in relation to the protection of the rights of migrants emphasized by local NGOs who have integrated the public awareness campaigns promoting the rights of migrants (and the attendant funds) in their traditional programmes for development and the fight against poverty ${ }^{18}$.

The actions focusing on female domestics are another point of articulation between different registers of discourse. The viewpoint of the unions emphasizes the defence of a particular category of workers (specifically female workers, in keeping with the concern for gender approaches of international organizations) who do not benefit from any protection convention. But they may also be treated from the viewpoint of "human

18 The unanimous protest now calling for the closure of the Nouadhibou retention centre is highly symptomatic of this type of misunderstanding: criticized by associations working for the defence of migrants as a site of arbitrary detention and a no-go area (see the 2008 report by Amnesty International), it is also considered by the IO as a stopgap solution that should disappear as a result of the tightened legislation and penalization of migration, which will allow for a fully legal closure and turning back (interview conducted with the managers of the Nouakchott branch of the IOM, February 2010). 
rights" and forced labour, which tends to emphasize the migration dimension of their situation in the context of human trafficking, even slave trade and slavery. It is quite explicitly from this angle that the issue is evoked by the CGTM: "At a strategic level we wish to reinforce the mechanisms of articulation already in place between activities focusing on public awareness and the defence of migrants as a whole, the protection and organization of the informal sector that covers established migrants, and finally the defence of domestics, conceived as forming a specific sector in connection with the problems of human trafficking and forced labour".

The approach is also given a more general formulation. During a training and information session held at the Guide Centre ${ }^{19}$, the coordinator of the centre, listing the difficulties faced by migrants included, in addition to discrimination and xenophobia, "forced labour and slave trade, which are contemporary plagues of migration which the union will need to confront in supporting victims".

The issue of illegality may thus be attributed to organizers of so-called "illegal movements for employment purposes" (in the words of the 143 convention on migrant workers of the ILO). It may also be treated as a vulnerability against which workers need to be protected by informing them of the dangers entailed by their illegal situation. In this last case, the distinction between the activities of the union (centred round keywords such as "rights of migrants" and "decent work") and the activities of the Mauritanian Association for the Fight Against Illegal Immigration (centred around keywords such as "plague" and "trafficking") is blurred. In any case it allows for sufficient bridges to identify them as partners working towards an "improved management of the phenomenon of migration by Mauritania".

The 2010-2011 action plan for the improvement of the living and work conditions of migrants, included on the website of the ILO, provides the list of the "implementation partners" and details the distribution of duties (and of the corresponding funds) ${ }^{20}$. It includes state organizations (Ministry of work), social partners (CGPM and CGTM), international organizations (IOM, BIT), and civil society (OSC) (besides the two organizations presented above, the APEAH of Nouadhibou and Caritas), required to carry out specific duties according to a division of tasks articulated around the contrast between the benefits of migration and the damaging effects of illegal immigration: missions of information on the rights and duties of immigrants (production of communication tools, media campaigns) entrusted to the AMLII and the CGTM, and missions of support for self-employment in the informal sector (particularly female workers) entrusted to associations such as Caritas and the APEAH, whose action is based on the developmental model characteristic of the "project culture" (Olivier de Sardan, 2005)..

19 Training and information session on the role of unions in defending the rights of migrant workers, CGTM/CSI project for the development of the capabilities of Affiliated Trade Unions, Nouakchott, January 22-24 2009.

20 The action plan was the result of a report by the ILO (Télou, 2009). Its recommendations were approved during a ratification workshop held in Nouakchott. 
The view of the Action plan as a tripartite association of "state institutions, civil society and foreign communities" tends to occlude a number of key partners: international organizations (IOM and ILO), who intervene in the early and late stages of the process in the elaboration of reference texts and the implementation of a national committee for migration management. This suggests several concluding remarks:

First of all, it is important to note that the increased intervention of actors of Mauritanian society in the implementation of a policy of migration does not replace the external actions which, as noted above, tended to be crucial in the period before the "migration crisis". On the contrary, this goes hand in hand with a process of legitimization of the intervention of international organizations: the preamble to the 2009 migration profile produced by the IOM insists that beyond the simple statistical reports which they originally constituted, migration profiles are designed to provide "government instruments for the development of policies". It emphasizes that "through mechanisms such as the GTTN and the national policy planning workshops, the reports also constitute an instrument of public awareness campaigns and inform the development of policy planning on international migrations in the targeted countries". It also insists that "the durability of government mechanisms created with a view to preparing migration profiles remains a major challenge". The compilation of data is not merely an end in itself, since it also provides procedures of rationalization (statistics, planning, consultation, creation of groups of experts) which migration profiles enable and aim to perpetuate.

While the police conception of the containment of migration flows is increasingly associated with the fight against terrorism and trafficking of all kinds (weapons, drugs), there has emerged a more managerial conception which transfers the management of circulation towards the administration of immigrant populations. The identification of these populations as belonging to specific formal categories (legal immigrants, immigrant workers, illegal immigrants), which made little sense in the traditional forms of mobility within the sub-region, becomes an integral part of the process of rationalization dominated by migration utilitarianism (Morice, 2000). The difficulties entailed by the formalization of the undesirable nature of transit migration have tended to demonstrate that the "legality" of the migrant was not a legal status so much as a social condition attested to by the relations fostered in local society and the possibility of the migrant to have a sufficiently influential guarantor. Albeit in slightly different terms, this was already the conclusion reached by the first "migration profile" written by the IOM in 2006. It is to this extent that it is important to interpret the recommendation of the European Union for a "formal integration of migrants in the economic sphere", included in the Document de Stratégie Pays (Country Strategy Document) signed by the European Union and Mauritania in $2007^{21}$. The adoption by the Ministry of Employment of a strategy for the management of foreign labour is directed at the same end. Its recommendations provide for a double foundation based on the national employment policy and the national policy for the entry, sojourn and settling of foreign nationals ${ }^{22}$. In

21 See http://ec.europa.eu/development/icenter/repository/scanned_mr_csp10 fr.pdf

22 Intervention by M. Fah Ould Brahim at the seminar on the Management of Labour Migration, coorganized by the ILO and the Ministry of Civil Service and Employment (Nouakchott, May 13-15 
this context, the adoption of regulatory measures defining the conditions for the employment of foreign labour (decree of April 16 2008) instituting a work permit goes hand in hand with the determination to "put an end to laxity" and to opt for political sovereignty according to which the presence of a migrant may be considered desirable or undesirable $^{23}$. The role of migration profiles is again decisive in this respect since they constitute one of the chief instruments aimed at favouring the implementation of state mechanisms that are liable to result in operations of categorization, "screening", and selection (Rygiel, 2004; Frigoli, 2010) between undesirable individuals and immigrants (whether legal or legalizable) who are liable to be integrated in the formal sector.

On the other hand, the role given to immigrant associations remains somewhat hollow: solicited as partners, the position assigned to them within the partnership depends on their willingness to play a game for which they have so far shown little aptitude. In Nouadhibou, the attempts to enrol them in public awareness campaigns about the dangers of illegal immigration have been met with a significant degree of resistance, prompting the IOM to abandon the implementation of a programme of "voluntary return". While the "ambiguity" of association leaders, suspected of being involved in illegal immigration ${ }^{24}$, was undeniable, it testified not to their position as intermediaries of Mafia networks (as suggested by the police conception) so much as a high degree of solidarity on the part of well-established communities of migrant workers upon which those keenest to embark on the adventure could rely in the course of their stay.

The process governing the formalization of labour migration tends to make the dichotomy between legal and illegal or migrant workers and candidates for illegal immigration all the more effective. The internalization of this shared ground (between formal and informal, legal and illegal, migrant workers and candidates for illegal immigration) by migrants themselves, the premises of which were observed in Nouadhibou $^{25}$, probably constitutes one of the major challenges (with as yet unknown results) of the new order of migration management in Mauritania.

Finally, one remaining question concerns the ways in which the actors of civil society tend to appropriate the theme of migration and contribute to its emergence as a social issue within the Mauritanian public arena.

Some organizations that are representative of civil society have fully integrated the situation of migrants as part of their militant themes. Such is the case of the AMDH, which relates the defence of free circulation to the defence of human rights. Such is also the case of the CGTM, which included the question of immigration within the union

2009). The records of the meeting are available on the website of the ILO: http://www.ilo.org/public/french/protection/migrant/afrique/events/nouakchott_mai2009.htm

23 "All the necessary measures will be taken in order to implement a complete census of foreign nationals, by ascertaining the reasons for their arrival and by granting visas to those who fulfil the required legal conditions" (translated from a government statement of general policy delivered before the National Assembly, January 62010 (http://www.primature.gov.mr/fr/index.php?link=1\&id=641).

24 Interview with the manager of the Nouakchott branch of the IOM, April 2007.

25 See the paper by J. Streiff-Fenart delivered at the "Migrations de transit en Afrique" conference held in Nice on December 10-12 2009 (forthcoming). 
strategies aimed at formalizing labour relations, in keeping with a rationale which, as noted above, is not altogether devoid of ambiguity. Other organizations, created piecemeal or already operating as relays of NGOs or IOs in other areas, have taken advantage of the recent implementation of migration management mechanisms produced by consultation and have widened their activities (training, surveys, public awareness campaigns) by entering this emerging market.

It appears therefore that within the generic notion of civil society, several distinct positions can be distinguished. At one end there has emerged a form of brokerage in which "developers of local social projects" involved in relations of dependence seek to appropriate the resources provided by the income of migration management (Bierschenk et al., 2000). At the other end, the formulation of warnings against public policies which entail the risk of racism and xenophobia leaves open the possibility of a politicization of migration that could undermine the consensus on migration management.

\section{$\underline{\text { References }}$}

Amnesty International (2008), Mauritanie: 'personne ne veit de nous'. Arrestations et expulsions collectives de migants interdits d'Europe, AI index AFR 38/001/2008.

Bensaâd Ali (2008) L'irrégularité de l'immigration en Mauritanie : une appréhension nouvelle, conséquence d'enjeux migratoires externes. CARIM-AS 2008/75.

Biersckenk T., J.-P. Chauveau \& J.-P. Olivier de Sardan (eds.) (2000) Courtiers en développement: les villages africains en quête de projets, Paris: Editions Karthala.

Carrera Sergio (2007) «The EU border Management Strategy, Frontex and the Challenges of Irregular Immigration in the Canary Islands», CEPS Working Documents $n^{\circ} 261$, March.

Choplin Armelle et Jérôme Lombard (2009) «La 'Mauritanie Offshore', extraversion économique, Etat et sphères dirigeantes», Politique Africaine, $\mathrm{n}^{\circ}$ 114, pp. 87-104.

De Haas Hein (2007) The Myth of invasion. Irregular migration from West Africa to the Maghreb and the European Union, University of Oxford, IMI research report, October 2007.

De Haas Hein (2008) Migration irrégulière d'Afrique Occidentale en Afrique du Nord et en Union Européenne: une vue d'ensemble des tendances générales, Genève, OIM, série migration research, no. 32 . 
Fresia Marion (2009) «Les enjeux politiques et identitaires du retour des réfugiés en Mauritanie: vers une difficile 'réconciliation nationale'?», Politique Africaine, $\mathrm{n}^{\circ}$ 114, pp. 44-66

Frigoli Gilles (2010) «Les usages locaux des catégories de l'action publique face aux situations migratoires », Migrations Societe, vol.22, no.128, mars-avril.

Mohamed-Saleh Sidna Ndah (2008) La migration irrégulière en Mauritanie, Notes d'analyse et de synthèse. Série sur la migration irrégulière, CARIM-AS 2008/52.

Morice Alain (2000) «"Choisis, contrôlés, placés” - renouveau de l'utilitarisme migratoire», Vacarme, $\mathrm{n}^{\circ} 14$, hiver, p. 56-60.

Olivier de Sardan Jean Pierre (1996) «L'économie morale de la corruption en Afrique», Politique africaine, $\mathrm{n}^{\circ}$ 63, pp. 97-116.

Olivier de Sardan Jean Pierre (2005), Anthropology and Development, Zed Books.

Rygiel Philippe (sous la dir. de) (2004) Le bon grain et l'ivraie. L'état nation et les populations immigrées, fin XIXème-début XXème, Presses de l'Ecole Normale Supérieure.

Streiff-Fénart Jocelyne et Poutignat Philippe (2008) Nouadhibou « ville de transit »? Le rapport d'une ville à ses étrangers dans le contexte des politiques de contrôle des frontières de l'Europe, Revue Européenne des Migrations Internationales, VOL 24 (2), pp. 193-217.

Télou Agathe (2009) Conditions de vie et de travail des femmes et hommes migrant(e)s d'Afrique de l'Ouest en Mauritanie, BIT, avril 2009. 